\title{
An Exploration into the Satiric Significance of Abuse in Selected Nigerian Drama
}

\author{
Author: \\ Oluwafemi Sunday Alabi \\ Obafemi Awolowo University, Ile-Ife, Nigeria \\ oluwafeminitemi@gmail.com \\ Date of reception: 11/01/2021 \\ Date of acceptance: $21 / 06 / 2021$ \\ Citation: \\ Alabi, Oluwafemi Sunday. 2021. "An Exploration \\ into the Satiric Significance of Abuse in Selected \\ Nigerian Drama." Alicante Journal of English Studies \\ 35: 143-162. \\ https://doi.org/10.14198/raei.2021.35.07 \\ (C) 2021 Oluwafemi Sunday Alabi \\ Licence: This work is licensed under a Creative \\ Commons Attribution 4.0 International License \\ (CC BY 4.0).
}

\section{Oluwafemi Sunday Alabi}

\begin{abstract}
:
A general survey of the contemporary Nigerian theatre and drama reveals that several contemporary Nigerian dramatists have harnessed the art of abuse-invectivesas a device for conveying meanings in their works and achieving their satiric goals. These dramatists create characters that engage abuse to articulate the thematic concerns of their drama, accentuate the conflicts in them, and establish the socio-cultural and political setting of their drama. Although extant works on satiric plays have focused on the use of language, and other satiric devices such as grotesque, irony, burlesque, innuendo, sarcasm, among others (Adeoti 1994; Adenigbo \& Alugbin 2020; Mireku-Gyimah 2013; Nyamekye \& Debrah 2016), sufficient scholarly attention has not been given to the art of abuse as a trope in Nigerian drama. The article explores the artistic significance of abuse and its forms in selected works of two contemporary Nigerian dramatists: Femi Osofisan's Altine's Wrath (2002) and Ola Rotimi's Who is a Patriot? (2006). These two plays are selected because they manifest ample deployment of the art of abuse and engage various sociopolitical issues. Hence, the article discusses how the art of abuse in these plays projects and addresses such sociopolitical realities as oppression, exploitation, resistance, self-interest versus national interest, and capitalism, among others. The article engages the principles of superiority theory of humour as espoused by Henri Bergson (2003) for textual analysis. It contends and concludes that abuse, as an inherent part of social and human interactions, has been an effective tool in satirising ills in individuals and society at large.
\end{abstract}

Keywords: art of abuse; satire; humour; Nigerian drama 


\section{Introduction}

Abuse has been described as "a variant of language use whose province covers diverse situations of human interactions ranging from insultive (sic) quarrels, correction and reproach for misdeeds" (Adejumo 2014, 226). It is a verbal face-off between two parties for the purpose of deriding each other for their offensive acts or for their moral or physical weaknesses. Abuse-Ėébú in Yoruba-as Adejumo $(2013,45)$ observes, functions especially in quarrel situations, "as a form of verbal combat where the parties involved exchange hot aggressive and insulting words."

Abuse is synonymous to insult and invective (Faleti 2014, 18; Feinberg 1985, 218); hence, it shall be used as such—i.e. interchangeably-in this article. Roller describes invective as a "vituperative mockery or other verbal abuse, couched in explicitly or implicitly moral terms, directed by the satirist against a target" $(2012,299)$. Roller's definition of invective does not only depict the similarity between abuse and invective, but also defines it in relation to satire. Abuse as a satiric element and as the satirist's tool of mockery, is usually aimed at denouncing, condemning or vilifying the personality and conduct of certain targets, mostly to ridicule them by exploring their personality traits, behaviours or physical features explicitly or implicitly. Its aim is to humiliate the target through the open declaration of faults. And in achieving this purpose, invective aims to arouse laughter and contempt against its addressee, thus becoming an indispensable rhetorical tool of satire.

Like Adejumo $(2014,266)$ observes, the "various annual festivals of cleansing" in many African communities have provided avenues for the society to "express anger against" and berate "individuals who have infringed on the community's code of conducts”. Traditional festivals in Nigeria such as Gèlèdé/Èfè, Èdi, Òpélú, Opéé Péé, Ęrù Òro or Pàkókó, Egúngún Pidánpidán or Alárìnjó have constituted themselves as agents of invective satires. For instance, on the Ėdi Festival day in IleIfe and its environs, the "Èdi choral group" (Ikó Èdi), on ascertaining the deviant acts of the victims in the community, goes straight to their houses and sings abusive songs to expose and ridicule them. This is with the intent to exposing the 'secret' acts of the targets to achieve deterrence (Oke 2018, 29). Again, according to Faleti $(2014,22)$ "the various non-professional groups of house-wife singers (àwon obìnrin-ilé), the men's group or club singers (Àwon egbé olórin - called Wáágá in Ogbomoso; Àgbáùnréré in Oyo and Bàrúwá in Ibadan), and the satiric Etíyerí singers which flourished soon after the Second World War provided the needed conducive environment which favoured the prolific use of gibes."

Instances of invective satires are also found in the enactments of the Yoruba Alarinjo theatre, Tiv Kwagh-hir puppetry theatre, Yankamanci Hausa comedy 
show in Nigeria, and Halo among the Anlo Ewes in Ghana, among many other indigenous traditional African theatrical performances. Halo, for instance, is a sociomusical drama ${ }^{1}$ that involves performance elements such as "songs of insult, dance, drumming, mime, poetry, spoken forms, costume, and a variety of visual icons" (Avorgbedor 1994, 84). During the performance, the rivalry groups mutually exchange abuse before a group of audience members to expose their moral and socio-cultural deficiencies, with the sole aim of holding the target accountable for their wrong-doing and to correct societal ills. It is on this theatrical mode-Halo, "a traditional African theatre of entertainment through mutual insult" - that Ola Rotimi modelled his play, Man Talk, Woman Talk (2006), a seriocomic play² (Rotimi 2006, 52).

In many situations where there is mutual exchange of abuse, like in Halo and Gèlèdé/Èfè, there are often three personae in the participant framework that constitutes its triadic structure. Faleti $(2014,17)$ identifies these participants as the "abuser", "the audience that witnesses the drama", and "the subject being insulted" (the abused). The abuser, in most cases, is the 'satirist' who engages abuse as a verbal rod to condemn anomalies in the target. The 'abused' is the target of the abuse, while the 'audience' is the entity on whom the ridiculous effect of the abuse rests. It can be contended that a drama that employs abuse is incomplete without any of these entities because when verbal duel takes place between only the abuser and the abused, it may not be effective as when the audience is involved. Pagliai $(2009,63)$ recognises this structure in her definition of abuse "as a genre of argumentative language that entails exchanges between two persons, parties, or characters that challenge each other to a performative display of verbal skillfulness in front of an audience."

Given the sociological and cultural attachment of abuse or invectives, dramatists have explored it in their works, as it forms a bulk of the interactional expressions of people in their day-to-day life. And since works of art-particularly drama - are set to represent the society and project social interaction in a realistic manner, Nigerian dramatists such as Wole Soyinka, Ola Rotimi, J. P. ClarkBekederemo, Femi Osofisan and Ahmed Yerima, among others, have explored

1 Avorgbedor (1994) describes 'sociomusical drama' (that is Haló) as a musical-dramatic performance that involves exchange of insulting songs between two rivalry groups in the public. It was an art popular among the Anlo-Ewe, from ca. 1912 until its official proscription in 1960 because of its social consequences, that is, the spectacular, the unusual, the precarious, havoc, danger, or challenge that is associated with it. The name has its etymology in ha + ló (song + proverb).

2 A "seriocomic play," as Ola Rotimi (2006) subtitles his plays, Man Talk, Woman Talk (2006), is a portmanteau word for a play that is partly serious and partly comic, a mixture of serious and comic elements. 
this art in their plays. It is also a handy tool in home videos. Hence, in this article we shall explore the significance of the art of abuse in addressing sociopolitical realities such as oppression, exploitation, resistance, self-interest versus national interest, and capitalism, among others in Femi Osofisan's Altine's Wrath (2002) and Ola Rotimi's Who is a Patriot? (2006).

\section{Satire, the Art of Abuse and the Concept of Humour}

Satire as a literary genre has its root in the Latin word satura which means primarily "full", and then comes to mean "a mixture full of different things" (Schlegel 2005, 4). According to Abrams (1999, 275), satire is a "literary art of diminishing or derogating a subject by making it ridiculous and evoking toward it attitudes of amusement, contempt, scorn, or indignation." Inherent in satire are elements such as "variety, down-to-earth unsophistication, coarseness, an improvisatory tone, humor, mimicry, echoes of the speaking voice, abusive gibing, and a general feeling, real or assumed, of devil-may-care nonchalance" (Highet 1962, 233). Accordingly, two things are essential to satire as pointed out by Frye (2000, 224): "one is wit or humor founded on fantasy or a sense of the grotesque or absurd, the other is an object of attack." This 'object of attack' could be an individual, group, institution, behaviour, trait or any form of deviance.

Hence, the main purpose of satire is to correct personal, moral, political and social ills. The satirists achieve this purpose either by humorous attacks on the target(s) or by serious scorn and hatred. This is the view of Highet when he states that "there are two main conceptions of the purpose of satire and two different types of satirists" (1962: 235). These two satirists are described by Highet thus:

One likes most people, but thinks they are rather blind and foolish. He tells the truth with a smile, so that he will not repel them but cure them of that ignorance which is their worst fault. Such is Horace. The other type hates most people, or despises them. He believes rascality is triumphant in his world; or he says, with Swift, that though he loves individuals he detests mankind. His aim therefore is not to cure but to wound, to punch, to destroy. Such is Juvenal. (235)

The Juvenalian satirists are considered as misanthropic, pessimistic, and tragedian satirists while the Horatian satirists are regarded as optimistic, and some sort of comedian satirists. Satire can also be classified according to the themes they deal with. From the earliest times-at least since the plays of Aristophanes - the primary concerns of satire have been politics, religion, and sexual misdemeanours; hence, political satire and social satire such as religious satire, satire of manners, sometimes also called comedy of manners. 
The techniques of satire include irony, sarcasm, invective (abuse), innuendo, burlesque, parody, ridiculous, exaggeration, wit, and humour among others. The list is not exhaustive; Adeoti $(1994,66)$ adds that "besides, scattered across the dialogue of a satirical drama are other techniques like hyperbole, meiosis, metaphor, innuendo, repetition, proverbs, apothegm, epigram, symbolism and so on." Thus, satire is not a direct and forthright expression of criticism or dislike; rather it uses these devices to express its criticism and dislike.

Invective, being the focus of this article, is a denunciatory, abusive or vituperative expression, either in spoken or written form. Adeoti $(1994,65)$ describes it as "a direct fulmination or verbal attack whose effect may be mild or severe." It involves the use of statements that are derogatory, offensive, scurrilous, defaming, hurtful, disgraceful, slandering, vilifying, irreverent, humiliating, scornful, disdainful, sarcastic, ironic, degrading, depreciative, stultifying, mocking, disparaging, jeering and scoffing, among others. Invective in literature is closely associated with satire, lampoon and caricature. Many writers have employed invective for a variety of purposes; the commonest is to express dislike, disgust, contempt and hatred for certain unwholesome phenomenon in the society. Dramatists use invective as an effective weapon to vilify a specific failing or moral weakness in a particular person, and occasionally a group of people.

Consequently, abuse (or invective) is a vital device for achieving desired humour and comic effects in satiric works. According to Neu (2008, 216), "insults can be done with good humor." Hence, when one carefully considers the employment of abuse in satire, one would find that abuse is a device for arousing contemptuous laughter, for giving the audience some kind of pleasure and for providing merriment for the audience, thereby releasing their repressed tensions. One would also realise that abuse is a device through which incongruity can be generated as a language style in a work of art; and also a tool for making the target (object of attack) ridiculous, thereby gaining some sense of superiority over them through laughter.

Though the term "humour" is not easily defined, it has always been described in association with laughter. Attardo $(1994,10)$ notes that: "[T] he assumption behind this identification of humor and laughter is that what makes people laugh is humorous, and hence the property is incorrectly seen as symmetrical-what is funny makes you laugh and what makes you laugh is funny. This leads to the identification of a mental phenomenon (humor) with a complex neuropsychological manifestation (laughter)."

Bergson $(2003,53)$, who views laughter as social phenomenon and whose work on laughter has greatly influenced the popularity of the superiority theory of humour, describes laughter as a response to social issues. Since laughter can be a form of derision, Morreall $(1982,5)$, who shares the same view with 
Bergson, opines that because people do not like to be laughed at, laughter serves as a social corrective to get wrongdoers back into line. Hence, laughter performs certain communicative functions. One of these is the effect that the speaker or writer wishes to achieve directly by inserting humorous contents or texts in his/her discourse.

Attardo $(1994,323)$ groups the effects of humour on the communicative process into four classes: "social management, decommitment, mediation, and defunctionalization." The most intriguing of these functions is social management function. It must be rightly established that satiric humour aims at correcting certain social misdemeanour, conveying social norms, and repairing damaged aspects of the society, among others. As Mathewson $(1920,7)$ suggests, "[I] $\mathrm{t}$ is the function of laughter to keep society safe and sane and to restrain each individual from shutting himself up in his own peculiar ivory tower."

Highet observes that a story or a play which only produces feelings of pure hatred and revulsion without a trace of scornful amusement or regretful contempt is not a satire $(1962,150)$. Consequently, abuse as satirists' weapon is purposely deployed to mock, giving its ludicrous and humorous modes of employment. Some of these modes are through sarcasm, epigrammatic interjections, wit, exaggeration, incongruity and irony, among other such techniques. Accordingly, Frye observes that abuse "is an established datum of literature that we like hearing people cursed and are bored with hearing them praised, and almost any denunciation, if vigorous enough, is followed by a reader with the kind of pleasure that soon breaks into a smile" (2000, 225). It follows that Frye is simply relating the humorousness of invectives as satiric element, or at best as satiric genre. Schlegel affirms that "invective thus provides a source of merriment for its audience, as long as the audience is not the object of its attacks" (2005, 78). And in achieving this purpose, invective "aims to arouse laughter and contempt against its target", thus becoming an indispensable rhetorical tool of satire (Roller 2012, 283). Similar to these submissions, Applauso equally posits that invective aims to give pleasure to the listener, because "the practice of blaming and insulting individuals occurred through hyperbolic and malevolent caricatures in which wit and humor were used in poetic invective to foster ridicule" $(2010,18)$. These devices give a perception of abuse as humour technique which will further be contextualised in this article.

\section{Abuse as a Tool of Oppressive Dominance and Resistance in Femi Osofisan's Altine's Wrath}

Altine's Wrath (2002) is one of Osofisan's social satires that focuses on issues prevalent in contemporary society-oppression, corruption, injustice, among others. Set in Northern Nigeria, Osofisan presents a photographic picture of 
corrupt public officeholders through Mr. Lawal Jatau, who is a typical Permanent Secretary in a government ministry. Lawal is a 'ten-percenter'3 and 'land-

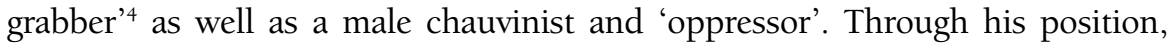
Lawal leads a corrupt lifestyle by gratifying himself with ten percent kickbacks from contractors, and taking over the land of the poor masses and usurping the compensations meant for them.

Lawal oppresses Altine, his wife who endures emotional, physical and domestic violence through his inhuman treatment, "which results in her dumbness'. Their marriage was arranged by their parents when they were young. Lawal uses Altine as the perfect conduit for his illegal wealth. He creates a new bank account that only Altine can access with her thumbprint so as to erase any trace of his corrupt actions. Altine is relegated to the position of a house help by making her serve his mistress, Mariam, even in her own house.

Ironically, Altine has only been playing dumb. She begins to speak at a provocation by Lawal, during one of his illegal dealings with Alhaji Maikudi. This surprises Mariam and Alhaji. She vents her wrath by recalling all the humiliation she has suffered from Lawal and his mistress. In the end, Altine responds to the poisoned banana, a gift left by Baba Audu and Mallam Onene on their visit with Dr Aina, Lawal's old friend, who come to plead for compensation for their acquired land. She is, however, revived by Baba Audu and Mallam Onene on their second visit.

In the play, Osofisan demonstrates the place of abuse in achieving oppressive dominance by people in vantage positions on their subjects. This is evident in the relationship between Lawal and Altine, his subjugated wife, Ahmed, his houseboy, Malam Onene and Baba Audu, local farmers whose lands are acquired. One of the four categories of invectives identified by Feinberg (1985, 222) is "symbolic dominance claims", others being "name-callings," "ritual accusations," and "expressions of scorn for what is deemed precious". This class of insults, Feinberg notes, aims at establishing and exploiting the inferior status of the addressee relative to that of the speaker.

Lawal engages this kind of abuse to subject Altine and make her totally insignificant. This is done by infringing upon her self-esteem, thus rendering

3 A 'ten-percenter' is a derogatory term for someone, who in spite of being paid their official remuneration for the service they render, still demands ten per cent of the money awarded for a contract from a contractor who is ready to pay. Lawal Jatau, who is a Permanent Secretary in a government ministry, engages in this act, which is considered corrupt.

4 A 'land-grabber' is a person, who takes possession of land belonging to other person(s) fraudulently, unfairly or illegally. Lawal unduly acquires the land belonging to Baba Audu and Mallam Onene, local farmers, for the so-called new layout by his Ministry; the compensation for the land had been paid but Lawal refuses to release it to them. 
her emotionally discomfited. One attitude that Osofisan inculcates in Altine to sustain her subservient pretense in order to elevate Lawal's ego and build up his follies to a ridiculous height that we see at the end is her habit with banana eating. This happens to be the first point of weakness that Lawal sees in Altine and abuses. Lawal wants Altine to attend to his visiting mistress, Mariam and so summons her. When Altine appears with a banana as usual, this provokes Lawal's rain of abuse on her: "[...] she's been cursed with it! Bananas! Always eating bananas!", and as if banana is a curse indeed or excrement, Mariam also expresses her disgust for Altine: "Disgusting" (5). This happens because of Altine's 'status and dumbness'. Apparently, Lawal has reduced her to nothingness and has placed her in the hands of his common mistress. This explains why Mariam can also exert herself on Altine.

Again, Lawal employs name-calling; he calls Altine monkey: "Monkeys, even monkeys have more self-respect!" (5). This is an ironic way of calling her an animal. Hence, irony-a rhetoric device of indirection-is employed here to debase Altine. Apparently, bananas are synonymous to monkeys. And so, such extended metaphor is employed by Osofisan to portray the oppressive disposition of Lawal. Lawal exploits her lowly state and her 'illiteracy' to misuse and violate her. This is a realist depiction, as it is a common behaviour of many people in a vantage position, and especially some abusive and cheating husbands like Lawal.

Lawal's employment of abuse evinces his attitudes and irritation for Altine as the case may be. For instance, when Lawal asks the eponymous character, Altine, to go and hang his visiting mistress's coat and get some food for her, the latter (Altine) simply stands and stares at Mariam. This irritates Lawal and Mariam to abuse her:

LAWAL: Why are you staring like an idiot? The least you can do is say good evening to her! [...] I say greet her, you dumb female goat! Down! On your knees! [...]

MARIAM: [... ... Ah, an animal! (6)

In another instance, Lawal engages abuse when narrating the incident that leads to Altine's dumbness to Mariam. He says: "There is nothing in that head of hers, except sawdust! Sawdust, yes! I've never met anyone as dim-witted as this woman you're looking at. A complete dumb clot!" (8). This is supposed to be a narration of Altine's dumbness but the speaker inserts some insulting elements in the speech. Lawal's irritation for Altine is equally seen in the manner he abuses and maltreats her when she mistakenly breaks the plate. He says to her: "You stupid imbecile! You broke that expensive plate! Why are you so clumsy, eh?" (9). These invectives show Lawal's intolerability for Altine for anything she does, 
because he sees her as an illiterate and subaltern, someone who lacks power for liberation - her parents are dead and has no one to ask after her.

Arguably, Lawal's achievements and social status inform his oppressive behaviours which manifest in the maltreatment of his wife and domestic staff, and ultimately his use of insulting language on them. Osofisan seems to be making a point on how many 'masters' treat their domestic workers and he appears to be making a demand for a change of attitudes. It is a common occurrence to see people like Lawal, using derogatory words on their subjects. For instance, when Ahmed is trying to inform Lawal that he has a visitor different from someone he is expecting, which is Alhaji, the only utterance that comes out of his mouth is abuse, couched on Ahmed's grandfather. He does not allow him to express himself, rather he says "It's what, you idiot? Your grandfather's ghost? Will you speak up!" (10). Even, after Ahmed eventually finds expression that the person gives him a card to give to him, Lawal's response to Ahmed is nothing but a subjugating one: "Then bring it, you ass!" (11). Were Ahmed a person of his calibre, he would not have addressed him in that manner.

'Power tends to corrupt, and absolute power corrupts absolutely. ${ }^{15}$ Given Lawal's ill-attained social status and ill-gotten wealth, he becomes so selfconceited that he finds it difficult to respect anybody, not even his old school mate, now Dr. Aina. Apart from Ahmed, Lawal also speaks contemptuously to other people of low estate, as depicted in Malam Onene and Baba Audu on whose behalf Dr. Aina comes pleading for compensation for their land that Lawal's ministry acquired, and whose compensation he usurps. He disdains them and would not allow them to sit in his presence, "not on my chairs!" He remarks discourteously: "The poor people always have a long catalogue of complaints. They are the only ones who suffer" (15). This implicit insult is a manifestation of Lawal's egocentric social status and privilege over the poor. Osofisan finds these behaviours and expressions archetypical of people in advantageous positions, especially in their relationship with the disadvantageous like Malam Onene and Baba Audu. So the expressions find employment in narcissists like Lawal.

Lawal engages abuse to subject the less-privileged even when they make attempts to voice out their concerns. He suppresses them, calling them "You wretches! You dare say such things in my house! Insulting your superiors like that!" (17). By implication, Lawal exerts his superiority over Malam Onene and Baba Audu and that is why he would not allow them to speak. Rather, he engages

5 This is an observation that a person's sense of morality lessens as his or her power increases; it is a statement made by John Emerich Edward Dalberg-Action, a British historian of the late $19^{\text {th }}$ and early $20^{\text {th }}$ centuries. 
insults to silence them and threatens to "get them locked up!" For Lawal, abuse becomes a weapon of oppression and a repressive apparatus.

Dr. Aina is apt at identifying the cause of Altine's dumbness as Lawal himself. Thus, she calls the audience attention to some male egoistic and patriarchal psyche which makes men to "think marriage is the modern version of Slave Trade" (13). This is actually Lawal's understanding and disposition. To Lawal, "Women here don't dare raise their voice when men are speaking!" and that also manifests in his encounter with Dr. Aina, his old school mate and even his 'crush' in secondary school-he demonstrates the same 'symbolic dominance claims'. He discounts her as less important than women that get into his bed.

To Lawal's self-conceitedness and oppressive personality, one can argue, Osofisan, in the spirit of Juvenal, deals a hard blow through a shrewd resistance from Altine, and of course Dr. Aina and Onene's confrontations. For instance, Osofisan uses Onene to confront Lawal, insulting him and other corrupt government officeholders like him. He says to Lawal when he tries to use government as a coverup for his heinous activities: "Nonsense! Which government? Is it not those rogues in those offices?" (17). By implications, Onene calls Lawal and his likes "rogues" which they really are as exemplified in the play. Dr. Aina equally challenges him: "The poor people, how many of their lands have you stolen? How many driven into the streets, to asylums? How many deaths weigh on your conscience, Mr. Fire and Thunder?" (19). Osofisan's voice and invectives against such individuals in the society is seemingly found in Dr. Aina's rhetorical expressions. The questions raised in the implicit abuse beg for answers from Lawal and his cohorts in the society. The perlocutionary effect of the abuse is seen in Lawal's reaction as contained in the acting instructions in parenthesis: "Choking. Long pause. When he talks, his voice is very cold" (19). Osofisan seems to be saying that sometimes, it takes courage to confront oppression, injustice, corruption and lawlessness in our society.

Osofisan's restoration of 'voice' to Altine is a technique he uses to effect resistance. Hence, 'voice' is used as a symbol of resistance and liberation. Immediately, Altine finds her voice, she frees herself from oppression, servitude and exploitation. She commands Mariam: "Quiet, you! Keep your mouth shut when I'm talking", and to Lawal, "I'm leaving the road clear now for you and your harlot" - the expression which has a devastating effect on Mariam: "[Stung] Who...who is harlot?" (30). The abuse equally debases Maraim of her egoistic dispositions that we see earlier on. Again, Altine resists Lawal's touchsomething which Lawal does at will before, even to maltreat her: "Don't dare put that your filthy hand on me again!" (31). Apparently, Lawal's hands are filthy and Altines makes him to realise that.

From the foregoing, it is obvious that the loud statement that Osofisan is making about Lawal's use of abuse to establish his oppressive dominance 
claims over his subjects is to allow him and his likes in the society to live in a fool paradise. Osofisan seems to build Lawal like that so that his fall can be catastrophic as it is at the end. That becomes a strong statement for the disillusioned oppressors in the society; someday, reality will dawn on them. Significantly, Osofisan engages the art of abuse in his plays to project his characters as well as to punctuate his thematic preoccupations.

\section{Abuse and the Quest for Social Re-Orientation in Ola Rotimi's Who Is a Patriot?}

Who Is a Patriot? (2006) is a social satire that is situated around an imaginary social problem - a robust rock blocking a national highway. Engaging epic theatre form, Rotimi focuses on the need to re-orientate Nigerians on the practical definition of patriotism and true nationalism. Rotimi assumes the position of a 'writer-teacher' who engages the teaching aid of drama to educate Nigerians on what is expected of them to build a united nation in spite of its diversity.

The play opens with the narrator perching on top of the rock and sternly asking from the audience "WHO IS A PATRIOT?" (5) The narrator introduces us to archetypes of several professionals and office holders-character types such as politician, lawyer, businessperson, academic, soldier, policeman, journalist and religious leaders among others-in search of a good citizen. The attitude of the Nigerian politicians is portrayed in the character of Politician who sees the problem (the rock) as a means of campaigning and making a name for himself. The capitalist tendency of many Nigerian businesspersons is represented in the character of Cash Madam whose only concern is her own "ten trailers from Cotonou" that will "pass here dis night" (6). The military-Soldier and Policeman-sees the problem as an opportunity to hijack the government: "Naim I tell my Captain. I say make all civilian patapata change one time to soldier, fa... so we all can get discipline-finish!" (7). All that Academic can do is to apportion blames on the Federal Government and the capitalist tendencies of the few rich in the country like Cash Madam and Politician. He cannot offer any 'solution' to the problem at hand. The unnecessarily prolonged procedure of the government in tackling urgent national problem is also emphasised through the character of Director General (DG) of the Ministry in whose jurisdiction the problem falls. When Christian Evangelist (CV) and Muslim Imam (MIM) arrive at the scene, they only quote the Bible and Quran and castigate the perpetrators without a suggestion on how the problem could be solved.

The problem is only solved by the concerted efforts of four boys, West, South, East and Minority who have their ankles tied together. The boys are a symbol of unity, interdependency, and indispensability. When the narrator asks 
them to make requests of whatever they want, they refuse to ask for materials and possessions such as money, power, fame, freedom, housing estates, among others. Their request is a united country free of corruption, favoritism, and where there is equity: "We want to feel convinced that this country belongs to all and we mean all. All of us! Finish! No one must feel that he has more right to it than others!" The narrator promises them that "The entire nation is listening. It's up to us to try... We shall try... It is a promise" (22).

Through the use of English Language and Nigerian pidgin English that contains vocabulary items from local languages-which indeed contributes to the play's comic orientation-the playwright employs invectives to condemn and ridicule certain traits among Nigerian citizens who fight only for their selfish interest at the expense of national interest. This is the central concern of the play. For instance, Lawyer ridicules the capitalist disposition of the Nigerian rich few as exemplified in the character of Cash Madam. She is only concerned about her ten trailers from Cotonou that are likely to collide with the rock, lying on the road instead of taking steps to remove it, for the good of all: "Hey! A-ya-yai... You're dead! (Raising to demonstrate as appropriates) Ten trailers! Full of flour from Cotonou, abi? The trailer in front: i-gb-u-gam on this rock at night. The remaining nine speeding behind: igbam, igbam into one another in the panic to avoid their crippled leader! Chineke!" (6).

Lawyer employs metaphor, onomatopoeia, visual imagery, hyperbole and apostrophe to abuse and ridicule the capitalist propensity of Cash Madam who is only concerned about her selfish individual interest at the expense of the national interest. To the playwright, a good citizen should be concerned about the well-being of the country. The ironic implication of the invective is that if a disaster befalls the nation, its citizens are not absolved.

Thus, Lawyer uses metaphor to spell her doom when he says "You're dead!" He also employs onomatopoeia to ridicule her selfishness and the imminent and colossal loss that it will bring to her. The use of onomatopoeia expressed in pidgin and the apt use of hyperbole and apostrophe make the abuse more grievous as they paint the picture of the loss in the mind-eyes of Cash Madam.

The psychological effect of the abuse is observable in Cash Madam's reaction. She "raises her arms heavenwards in distress" and eventually collapses in Lawyers' arms (6). This explains the traumatic effect that abuse can have on the target, depending on its grievousness, weight and mode of presentation. In the case of Lawyer, his mode of abuse includes language device, demonstration and body histrionics.

Lawyer and Politician also engage Cash Madam in taunting — a mode of abuse-for more satiric effects: 

LAWYER: $\quad$ All the ten trailers... they skid t-r-i-i-i... fall over! The multimillion naira cargoes.
POLITICIAN: I-i-i-i-w-o-sh-a-a-a, I tell you. All over the highway.
LAWYER: Very common.
POLITICIAN: Bags upon bags of Cotonou flour come masha-masha inside rain water! Kai!
LAWYER: Madam. When is your funeral date? (CASH MADAM collapses in his arms) Not yet, Cash Madam. Don't die yet!
POLITICIAN: (Propping her up bodily) You wan waste your die? (6)

The above is an example of mockery achieved through the use of imageries that appeal to the senses of sight and hearing of the target. The import is to engage her imagination in the likely repercussion of her unpatriotic attitudes. The mockery forces through Cash Madam's mind to make her see and hear her doom ahead, even when it has not really happened. Lawyer traumatises Cash Madam as he asks for her "funeral date." This further emphasises psychological implication of abuse on the abused.

Apart from mockery and taunt, Lawyer also engages metaphor and namecalling to devalue Cash Madam. He calls her "suegbe woman"-a foolish woman - when she resorts to suing the government. Rotimi sees the act of suing the government for an issue that is civic as barbaric and ridiculous; thus, he satirises the businesswoman for such act. Again, the woman is called "Moneymiss-road" by Politician for intending to sue the government aimlessly. As a capitalist, her constant aim is exploitation, not only of the masses but also the government. When she is advised to sue the government for "millions and millions of naira", she becomes so excited and goes ahead to strategise and file a case with her Lawyer. The playwright engages the art of abuse to ridicule such an act which is common among many Nigerians.

In a way, the abuse of Cash Madam by Politician and Lawyer portray them as more loyal and committed to the nation's well-being than the woman. This is a superiority tendency by Politician and Lawyer in the play. However, the superiority predisposition of Lawyer and Politician is absurd because there is a contradiction in their characters and their actions. Rotimi presents them as 'pots that call the kettle black.' In a way, the playwright indirectly satirises Lawyer who is also abetting the suing of the government by Cash Madam. More so, political office holders and capitalists like Politician and Cash Madam are abused and called "ochlocrats" and "baboons" by Academic: "When people like you constitute yourselves into consummate syndicate of ochlocrats set to pauperize labour in system that rhapsodizes the sadism in that capitalist dogma of 'monkey work; baboon eat"” (9). 
Metaphor is used in the abuse to castigate the exploitative activities of many African political leaders and their "capitalist dogma." The use of antithesis "monkey work; baboon eat" portrays and condemns class disparity and hegemonic structure of many African societies. It condemns "the sadism" (9) that characterises capitalist-labour relationship-the suffering that the labour experience from moneybags like Cash Madam.

The expression 'baboon' is also an indirect abuse cast in metaphor, which Kodah $(2012,7)$ regards as "symbolic invective." It involves a metaphoric replacement of characters by animals or things. Through this technique, the playwright denies the characters of their human features and replaces them with animal characteristics which consequently make them vulnerable to general ridicule and derision. The psychological effect of the abuse is seen on Politician. He is visibly hurt and responds thus: "My friend, I am not baboon! You hear?" (9). Rotimi portrays political office-holders as represented in the character of Politician and the few rich like Cash Madam as exploiters of masses and 'baboons' who take advantage of the poor and pauperise them.

Academic's disdainful remarks against Politician "Mr Politician, think of the good of the people. I challenge you! Be a good Samaritan I say!" (10) is an indirect abuse through the use of irony. Although the invective is directed at Politician, it is a call to the politicians in the nation to have the interest of the people at heart and not selfish interest of their own. Cash Madam's consolatory response to Politician against the opprobrious remarks by Academic is equally disparaging: "I no talk? Bukuru people-dem be people?" In essence, she abuses "academics" for their complexity.

There is a comic dimension to the verbal exchanges between Politician and Cash Madam:

POLITICIAN: He challenged me to be wetin?"

CASH MADAM: I know?

REPORTER: To be a 'Good Samaritan'

POLITICIAN: I see. First, I am to be a baboon. Then a good wetin call it? (10)

The emphasis placed on "baboon" explains its perlocutionary effect on the abused-Politician. This demonstrates the lasting impact that abuse can create in the mind of the abused.

The internecine enmity between the civilian and the military is emphasised in the play through the device of abuse. This is represented in the characters of Politician and Cash Madam, and Soldier and Policeman respectively. Rotimi represents this through dialogues and actions of the characters to ridicule the 
weaknesses in both systems of government. For instance, Soldier and Policeman criticise democracy as a system of government where indiscipline abounds. For example, when they get to the scene of the rock, they cast several aspersions on the civilians for their acts of indiscipline and highhandedness:

SOLDIER: You see... you see am? Finish! I mean, how can man who no
crase for head, ehn-tell me, brother... How can man who love
this country... I say how can he do a crase thing like this? See
am?

POLICEMAN: Nonsense civilians, in short! I swear, dis thing go fit stay here gbagala-a-a like this forever and ever, in short.

SOLDIER: Enheen now.

POLICEMAN: Lazy civilians! All bloody civilians, mana! (7)

Rhetorical questions, repetition and name-calling are employed in the above excerpt to raise criticisms against the civilians. Through the use of rhetorical questions, Soldier presents the insanity that characterises civilian administration, whereby citizens are indifferent to the welfare of the nation. The repetition of "crase" emphasises on these acts of indiscipline (crase thing) and their perpetrators (crase head). It expresses their lack of compatriotism to the nation. The repetition of "civilians" seems to show their disregard and indignation against them because of their attitudes to nation's wellbeing. Thus, they call them names such as "nonsense civilians," "lazy civilians" and "bloody civilians." The playwright creates the characters of Soldier and Policeman to abuse the civilians for their acts of indiscipline and lack of commitment to the good of their nation.

The contemptuous remarks by Soldier and Policeman when they sight Politician and Cash Madam coming back to the scene emphasise the hatred that exists between military and civilian. The statement by Soldier: "E be like say bloody civilian dem dey comesef!" and the response by his colleague, Policeman: "Me no wan see dem, I beg... (Turns in the opposite direction)" substantiate this (8). However, the failure of the military in its responsibility to entrench discipline in the country is also ridiculed in the dialogue. Soldier who has initially sought his Captain's order to convert all the civilians to soldiers has been made to realise by the Captain that soldiers and police have the responsibility to protect the civilians and to show them how to be disciplined by their acts of discipline. But Policeman calls it "Nonsense discipline!" while Soldier remarks: "Shey na me, Soja, go come dey show bloody civilian di driver discipline of how to commot rock for expressway?" (8). Apparently, Policeman and Soldier do not see it as their responsibility to instill discipline in the citizenry. However, Rotimi re-enlightens the audience that the issue of patriotism does not leave out any citizen, military or civilian. 
In another instance, Politician and Cash Madam taunt Reporter because she reminds them of their civic responsibilities to their nation:

REPORTER: But I thought you were both responsible to the challenge which...

POLITICIAN: Challenge, abi? You like challenge. Go become labourer, fa. Oya commot blouse, pull skirt up papa. Den push rock commot road. Oya! You be Good emm... Good Samanja!

CASH MADAM: (Hisses) yeye girl! (12)

Politician and Cash Madam use taunt in the above excerpt - a form of retaliatory invective-in response to Reporter. Apparently, Politician and Cash Madam are birds of a feather who are not ready to be socially responsible to their nation. Because of their status, they believe it is the responsibility of "labourer"- the masses to do that. That is why they challenge Reporter to "go become labourer." Cash Madam also "hisses" on Reporter to show her displeasure against her (12).

The late response of Director General of the 'Ministry of Works and Emergency Management' to the problem is condemned through abuse. Reporter questions the Director General who claims his ministry "took action in a jiffy" as soon as he learnt of the problem: "In a jiffy, but you're just arriving..." (13). By implication, Reporter's statement, ridicules the lackadaisical attitude of the ministries to an issue that requires urgent attention from the officials. At the root of the problem is bureaucracy and redtapism. For instance, to evacuate the rock, the ministry must list the specifications of the problem, convene a Ministerial Consultative Committee Meeting to deliberate on the report, prepare budget for the 'project' and run adverts for the enactment of the 'project', among others. The playwright carefully highlights and condemns these procedural steps that are involved in solving an urgent national problem like the removal of a rock from the Highway.

Director General also abuses Reporter for the inquisitive nature of her profession: "You Press people can be so inquisitive, I tell you. Investigative Reporting you call it, ehn? (Chuckles) Allright. Shoot on. So you don't tell the world that this man refused to cooperate, if you get my meaning" (14). In essence, DG ironically abuses the ethics of her profession.

Foreman derides Nigerian power sector for its epileptic supply of electricity. This is evident in his remark to his workers: "Oya, make una pack up-I beg. Night wan come and NEPA no sabi dis place!" This is a gibe against the Nigerian power sector. Foreman uses irony in this abuse to paint a picture of inefficiency and lack of patriotism in some ministries and departments in Nigeria. 
In the same vein, the role of the politicians in religious crises in the nation is $\mathrm{x}$-rayed through the device of abuse in the play. The level of cordiality between Christian Evangelist and Muslim Imam shows that both religions can co-exist peacefully. Hence, both CEV and MIM accuse and abuse the politicians for being responsible for division that exists between them:

$\begin{array}{ll}\text { REPORTER: } & {[\ldots] \text { both of you chatting away and laughing together-just like }} \\ & \text { brothers! } \\ \text { CEV: } & \text { But we are brothers, young lady! } \\ \text { MIM: } & \text { The same sons of Adam, lady, and brothers in the same land. } \\ \text { CEV: } & \text { Patriots too. } \\ & \text { The politicians, lady. Blame them for everything to rip us asunder } \\ & \text { for their own selfish goals! } \\ \text { MIM: } & \text { But their's will be the disgrace of failure! Inmates of hellfire that } \\ & \text { they all are! (16) }\end{array}$

CEV and MIM abuse the politicians for ripping them apart because of their selfish interest at the expense of peaceful co-existence of the nation which they claim they love and have come to lead. MIM curses all agents of disunity and division among them and regards them as "Inmates of hellfire". He uses this form of abuse to castigate and ridicule the politicians so as to effect change.

Abuse is used to castigate Reporter for her inability to open the Quran appropriately. MIM abuses her when he gives her the Quran to read and the latter turns the pages of the Quran left to right, instead of right to left. MIM yanks the Quran off her hands and gibes: "Foolish girl! (Nudging CEV) Come, my brother, let's move away from Unbelievers! (Surlily, to REPORTER) All that your generation knows best to turn are pages of Tempo Magazine!" (17). MIM considers anyone who does not know how to handle the Quran "a fool" and "an unbeliever." This, however, is one of the extremities in religious dogma; perhaps the fellow is a Christian. But the implication here is that the lady is an addict of magazines rather than Holy Books. Hence, the abuse is directed at youths who celebrate fashion and mundane things at the expense of religious practices.

Abuse is also employed in the play's denouement. When the boys who roll the 'rock' away from the road are asked by the narrator to make a request of what they want, the adult characters which include Cash Madam, Policeman, Politician and others beckon on them for advice. However, because the boys refuse to heed Policeman's advice of bribery through the tactics of "Wetin una carry," he calls them "Nonsense Boys" (21). Similarly, Cash Madam abuses the boys because they refuse to follow her advice which is to ask for "Money... cash—hard currency." She calls them "crase pikin" (22). Here, Policeman and 
Cash Madam employ name-calling to show their indignations towards them. This demonstrates the possibility that abuse can be used on target whose ideology is contrary to that of the abuser. This is mostly to vent spleen on their target.

Evidently from the analysis, Rotimi engages abuse not only to ridicule ills in the society and discount the culprits but also as a mode of correction and enlightenment for positive change in the society. At the end, the playwright allows the audience to make commitment in fulfilling the boys' requests. He commits the audience (the society) to having change of attitude towards their nation as taught by the narrator.

\section{Conclusion}

This article has demonstrated that abuse, as one of the linguistic codes of human interactions, has some aesthetic values in drama, where it has been frequently employed. The article has shown the place of abuse in the aesthetics of Nigerian drama, acknowledging how some contemporary Nigerian dramatists such as Femi Osofisan and Ola Rotimi, among others have employed the art in their drama for artistic effects, importantly as a device to create and sustain comedy as well as to satirise human foibles and societal inadequacies. In these plays, the playwrights significantly engage invective aesthetics to address some sociopolitical realities such as oppression, exploitation, resistance, self-interest versus national interest, and capitalism, among others. For instance, Osofisan's engages the art of abuse to establish the oppressive dominance of the privileged in the society over their subjects, somewhat to allow them to live in a fool paradise, such as we see in Lawal, whose end is catastrophic. Hence, Osofisan employs the art of abuse in his plays to project his characters as well as to punctuate his thematic preoccupations. Similarly, Rotimi engages abuse not only to ridicule vices in the society and discount their perpetrators, but he also explores it as a mode of correction and enlightenment that effect neo-orientation in them for nation transformation.

This article has mainly focused on the significance of the art of abuse in Nigerian drama. However, it is recommended that other art forms that engage in the use of abuse such as standup comedy, comedy skits and social media comedy such as Mark Angel comedy, Woli Agba, Mr. Macaroni, Broda Shaggi, Taaooma, Remotecomedy etc, and even cartoons/comic strips and home videos could also be explored by future researchers who are interested in the study of the art of abuse. The significance of abuse in other literary genres such as prose fiction and poetry can also be examined. More so, other theoretical frameworks could also be engaged in the study of the art of abuse in any of these art forms. 


\section{Works Cited}

Abrams, Meyer Howard. 1999. A Glossary of Literary Terms (7th Edition). Boston: Heinle and Heinle.

Adejumo, Ade. 2013. "Satire as Protest in an Indigenous Festival: The case of Efe." International Journal of Humanities and Social Science Invention 2(7): 43-50.

—. 2014. "An Exploration into the Satiric and Poetic Imagination of Yoruba Abuse." International Journal of English Literature and Culture 2(11): 266-270.

Adeoti, Gbemisola. 1994. "Nigerian Literary Drama and the Satiric Mode as Exemplified in Wole Soyinka's Works.” M.A. Thesis, Obafemi Awolowo U.

Applauso, Nicolino. 2010. "Curses and Laughter: The Ethics of Political Invective in the Comic Poetry of High and Late Medieval Italy." PhD diss., U of Oregon.

Attardo, Salvatore. 1994. Linguistic Theories of Humor. Berlin and New York: Mouton de Gruyter.

Avorgbedor, Daniel. 1994. "Freedom to Sing, License to Insult: The Influence of Haló Performance on Social Violence among the Anlo Ewe." Oral Tradition 9(1): 83-112.

Bergson, Henri. 2003. Laughter: An Essay on the Meaning of the Comic. London: Project Gutenberg Etext.

Braund, Susanna and Josiah Osgood, eds. 2012. A companion to Persius and Juvenal. New York: Blackwell. https://doi.org/10.1002/9781118301074

Faleti, Adebayo. 2014. "Uses and Abuses of Yoruba Invectives." IFE: Journal of the Institute of Cultural Studies 10: 7-33.

Feinberg, Joel. 1985. Offense to Others: The Moral Limits of the Criminal Law. New York: Oxford UP.

FrYe, Northrop. 2000. Anatomy of Criticism: Four Essays. New Jersey: Princeton UP.

Highet, Gilbert. 1962. The Anatomy of Satire. New Jersey: Princeton UP.

KoDAH, Mawuloe. 2012. "The Aesthetics of Invective: Reflections on the Use of Verbal Violence in The Suns of Independence of Ahmadou Kourouma." IOSR Journal of Humanities and Social Science (JHSS) 3(5): 1-08. https://doi.org/10.9790/08370350108

Mathewson, Louise. 1920. "Bergson's Theory of the Comic in the Light of English Comedy." University of Nebraska Studies in Language, Literature, and Criticism 11: 3-27.

Morreall, John. 1982. Taking Laughter Seriously. New York: State U of New York P.

Neu, Jerome. 2008. Sticks and Stones: The Philosophy of Insults. New York: Oxford UP. https://doi.org/10.1093/acprof:oso/9780195314311.001.0001

OKE, Olusegun. 2018. "The Socio Religious Significance of Edì Festival Song in Controlling Marital Infidelity in Traditional Marriage Institution in Origbo Meje, Osun State Nigeria." Global Journal of Human-Social Science (A) 18(4.1): 25-34. 
Osofisan, Femi. 2002. "Altine's Wrath." In Seasons of Wrath: 5 Short Plays. Lagos: Concept Publications, 1-38.

Paglial, Valentina. 2009. "The Art of Dueling with Words: Toward a New Understanding of Verbal Duels across the World." Oral Tradition 24(1): 61-88. https://doi.org/10.1353/ort.0.0054

Roller, Matthew. 2012. "Politics and Invective in Persius and Juvenal." In Braund and Osgood 2012, 283-311. https://doi.org/10.1002/9781118301074.ch13

Rotimi, Ola. 2006. "Who is a Patriot?" In Four One-Act Plays. Ibadan: UP, 1-22.

—. 2006. "Man Talk, Woman Talk." In Four One-Act Plays. Ibadan: UP, 51-96.

SCHLEGEL, Catherine. 2005. Satire and the Threat of Speech: Horace's Satires, Book 1.

Wisconsin: The U of Wisconsin P. 